\title{
An Anatomy of the Collective Unconscious of Leading Women Writers
}

Jency Christafer

PG \& Research Dept of English

Fatima Mata National College (Autonomous)

Kollam, Kerala, India

Dr Cynthia Catherine Michael

Assoc. Prof \& Head

PG \& Research Dept of English

Fatima Mata National College (Autonomous)

Kollam, Kerala, India

cynthiamichae12006@yahoo.com

\section{Abstract}

This article intends to explore the concept of feminism as presented in the works of Virginia Woolf, Mary Ann Evans, Jane Austen, Sylvia Plath, Kamala Das and Maya Angelou.A selective study of their works is conducted to exhibit the ways in which they presented the woman characters in order to deal with socially relevant issues. Woman victimisation, racism, discrimination etc become the major focus of these writers. This article investigates the collective unconscious realm of these writers and how it influenced them in their writing. The writers' individual conception of feminism is also studied and critiqued. The traditional conception of beauty, perfection in the works of writers like Petrarch had resulted in the general objection from the women writers and it led to the representation of women 
characters in their novel quite differently. The article brings to light the minute flaws in the approach of the women writers and concludes by highlighting their contribution to feminism.

Keywords: Feminism, Unconscious, Female, Relationship,

Feminism is a movement that has spread its wings throughout the world. It is concerned with gender issues and works towards women's empowerment. Its major focus is on eradicating gender inequality. Throughout history, women are forced to live in a framework created by societal norms. Feminists have come forward to fight for the women's rights and give them a space where they can enjoy freedom. They adopted various methods to exhibit their contempt towards the established laws that threatens female independence. Feminism can be likened to an individual who exhibits versatility. It appears in various disguises in different societies.

Literature soon became a vehicle of feminism. It became necessary for the society to know the various atrocities faced by women. The medium used to convey the women's suffering was literature. Throughout the ages, women had no voice in their homes or in their society. They were forced to do household chores and remain uneducated. They were objectified and ripped of their identity. Continuous torture led the women to speak out for themselves. Some bold women came forward and fought against the army of hypocrites with the magical pen. It was their weapon to liberate themselves from the clutches of the society.

Feminism soon established itself in literature which was earlier a space dominated by men. There were many feminist writers and feminist critics. They created a world for them to present reality through words. Some female writers were not feminists but their literature somewhat exhibited feminism. This happens naturally because they are part of the tormented and subjugated generation. The sufferings of their ancestors runs in their blood and forms 
part of their collective unconscious. This unconscious representation of feminism needs to be studied and it can only be done through an analysis of female writers.

Virginia Woolf is an English writer as well as a feminist. It is quite evident in her works that she fights for female independence. Her monumental work A Room of One's Own presented her ideas regarding female subjugation. This work is based on her two lectures delivered at Cambridge University. Her central focus was female writers and their writings. She felt the need to motivate the female writers towards creating excellent works. She recognised the need for women writers to become more creative in their writings. She tried to cure them of their fear of being rejected in the literary world. Woolf therefore created a fictional sister for Shakespeare named Judith. Woolf presented the tribulations faced by a female writer through Judith's character. Woolf says that during Shakespeare's time no woman identical of Shakespeare's merit was accepted. The society favoured male writers. The men were given opportunities to educate themselves and flourish in their career. Judith is representative of the unrecognised talent and tormented female identity. Therefore, Woolf asks the female writers to create a room of their own and establish their identity. She says "A woman must have money and a room of her own if she is to write fiction" (Woolf goodreads.com) The feminism of Woolf thus focused on domestic and financial freedom. Her works focused on the female writers and their writings. She was concerned about their plight. She was empathetic to the secondary importance given to the female writers. Her collective unconscious thus comprised thoughts concerning female writers. This consciousness thus got represented in her writings.

Mary Ann Evans is a prolific novelist and is better known by her penname George Eliot. She is not a feminist and she remained inactive throughout life. She had offered financial help for various social causes but remained aloof from actively engaging in feminist activities. Literary field was still dominated by male writers. This played a vital role in her 
decision to use a pen name. George Eliot was a bold woman and she was ready to break conventions. During her time,female writers were expected to write romance novels but Eliot deviated from the convention. Her novels were realistic in nature and splendid with literary allusions. Eliot made her novels a fighting weapon against the conventions of the day. Her female characters were not entirely good. In her novel Adam Bede, we witness the relationship between Hetty and Captain Donnithorne. Hetty loves the wealth and social status of Donnithorne. Their relationship ends soon leaving Hetty pregnant with Donnithorne's child. Hetty murders her baby and for this heinous crime, Hetty is sentenced to death. Hetty's fate may be questioned by feminists but Eliot makes her stand clear by punishing the wicked women while presenting the meek and silent women suffering under the wrath of the societal norms. Eliot exposes the types of women in the society. She is not a blind feminist supporting everything what a woman does. In Middlemarch she presents marriage as the central theme. Marriages in which women plays a central role may last long, an idea which is made evident in the relationship between Fred and Mary. Dorothea and Casaubon struggles because Casaubon tries to exercise control over their relationship. Here Eliot exposes the negative impact of confining women to their domestic sphere. In The Mill on the Floss Eliot presents the issue of women remaining uneducated while the men are given adequate opportunities for education. Maggie Tulliver remains uneducated while her father finances her brother Tom's education. She is also looked down upon for her dark colouring and activeness and intelligence. Maggie is treated as an outcast after her family finds out her affair with Stephen. She is deprived of freedom. Her life is controlled by others. And finally, she dies in a flood. Eliot's novels often end in tragedies because she presents reality. Mary Ann Evans thus presented the good and evil side of women and dedicated her works to represent justice. Her collective unconscious was concerned about all the issues concerned with women in different 
spheres, including herself by adapting a pen name to ensure an unbiased reading of her works.

Jane Austen is a bold woman who tried to wage war against all the discriminations in the society through her literary works. She was concerned about how women were tormented during Elizabethan period. Through her work Pride and Prejudice Austen tried to present the Elizabethan women, their mentalities and the societal prejudice. During Elizabethan period women are expected to create an identity through marriage. The parents try to get their girls married to rich upper-class men. Mrs Bennet in Pride and Prejudice represents the oldfashioned women of Elizabethan era. Women like Mrs Bennet try to follow societal norms. Lady Catherine in the novel represents society with all its prejudices. She tries to do everything in order to create a rift between Elizabeth Bennet and Darcy. But finally love triumphs by defeating all the prejudices. Elizabeth Bennet stood against all the prejudices and believed in love. Jane Austen identifies herself with Elizabeth Bennet. She is a woman with high esteem and intelligence. Jane Austen thus presented love as an escape route from all prejudices in her novel. Her collective unconscious is all about protest and standing for woman and exposing the prejudices in society while urging people to break free from the clutch of societal norms.

Sylvia Plath is a confessional poet, therefore her poems often embody her psychological problems and her inner self. Plath finds herself as a victim of various prejudices against women. Her personal life is pathetic and she used poetry to express her emotions and protests. During an early age her mother was preoccupied with her sick son and never had time to pay attention to Sylvia Plath. Plath turned towards her father for comfort and care but it was totally declined to her. In her poem Daddy she expresses the relationship she had with her father and the tyranny under which she suffered. She says, "I thought every German was you. /And the language obscene/An engine, an engine Chuffing me off like a 
Jew. /A Jew to Dachau, Auschwitz, Belsen. / I began to talk like a Jew. /I think I may well be a Jew"(Plathpoetry foundation.com). Here Plath makes a reference to the Jews who suffered under Hitler. Hitler is a German and it is an obvious reference to her father while she compares herself to the devastated Jew who is continually tortured in concentration camps. She was refused the personal freedom and was treated like an object. Her poems therefore become a protest against commodification of women. Plath was preoccupied with the idea of death and she very often makes reference to personal decay in her poems which goes against the traditional depiction of woman's beauty. This is evident in her poem Lady Lazarus in which she explains her various suicide attempts and the ways in which she returned to life as the biblical miracle in which Lazarus was brought back from the dead by Jesus. Thus, Plath tries to protest against the lack of freedom and the trend of the commodification of women through her poetry.

Kamala Das is an Indian English poet who is an activist of strong mentality. She often dealt with bold subjects expressing the sexual emotions. She objected to the patriarchal norms and tried to reset the mentality of the narrow minded public. Her works often dealt with the life of women and their roles as a mother, a victim and as a one who suppresses their emotions. Kamala Das was criticised for conveying sensitive subjects in her poems. She was straightforward and redefined her identity. She had made bold statements on many matters. Das had once said, "If wrappings of cloth can impart respectability, the most respectable persons are the Egyptian mummies, all wrapped in layers and layers of gauze" (Das vagabomb.com). In her works like My Grandmother's House she presents her contempt for her present life while she recollects her memories in her grandmother's house as a remedy to her present loneliness. Her works were mirrors that reflected her anxieties and protest. She describes herself as "I am sinner, I am saint. I am the beloved and the betrayed" (Das vagabomb.com). This statement encompasses her whole personality and her life. The 
feminism she propagated was to liberate oneself from the clutches of one's own demons and boldly retaliate the misconceptions in the society with one's words and identity.

Feminism thus finds place in almost every work of female writers. One might wonder the reason behind female writers' obsession with the concept of feminism. It is their personal experience and their social background that motivates them to write works that express their protest against societal forces that creates a framework for women. Maya Angelou is an American writer who stands out from all the women writers. Angelou never complained or protested against anything but she tried to embrace her identity and expressed pride for her distinct self. Through her works she tried to motivate the oppressed to rise up and have confidence in their power to stand against all the odds. Angelou dealt with issues like racism and discrimination. In her work Phenomenal WomanAngelou describes the secret behind her success. She says, "It's the fire in my eyes, And the flash of my teeth, The swing in my waist, And the joy in my feet. I'm a woman / Phenomenally. /Phenomenal woman, That's me" (Angelou). Maya Angelou is proud of herself and she made the things which other people thought as her weakness to be her strength. The concept of feminism she propagated was inspiring and motivated the oppressed to love themselves despite the criticism society bestows upon them.

Literature is indeed a weapon used by these women to create their identity. It is also a silent protest against the literary depiction of women in the literature of old times. Writers like Petrarch were obsessed with the conception of beauty and perfection. Petrarchan sonnets give ethereal qualities to the woman. Women are expected to encompass all the virtues and is presented as the epitome of perfection. It is this idea of perfection that the women writers are trying to dismantle in their works and draws attention to the fact that they are human and they have their flaws like any men and this establish their right to be treated as equal to men. The ideal concepts like beauty and perfection is a myth therefore it never exists. Women writers 
pave the way to expose this truth to the people and open their eyes to the misconceptions they have.

Regarding the works of these women writers, one major question that arises here is that why do they often deal with subjects like discrimination, prejudice, etc frequently in their works. Some writers often fail to think out of the box. While analysing the selective works of these writers one may find that they lack the genius of a great writer. Women writers are overwhelmed by their social conditions and personal experiences. They focus on liberating women from the clutches of societal norms but in the process some of these writers failed to pursue greater things that might improve their social standing. Instead of working towards making people accept them, it would have been better if they created works of excellent quality and through it they could have proved that they are no less than men. This is a major reason behind the fact that we do not have a woman's genius praised as Shakespeare's.

Mary Ann Evans' usage of the pen name, George Eliot is not inspiring but demotivating the women. The social conditions are created, they do not occur naturally. The societal norms, practises and conceptions arise from the minds of people. Therefore, instead of hiding one's personality to get accepted in a society, it is better to expose one's real identity and work towards making the society accept them rather than creating a false identity and accepting what the society propagates. Maya Angelou is a great personality who executed this idea of accepting one's identity and making the society accept them. She says, "Each time a woman stands up for herself, without knowing it possibly, without claiming it, she stands up for all women" (Angelou goodreads.com). All the women writers have made immense contribution to literature and helped in redefining women's identity in their own distinct ways. Feminism which initially appeared behind a mask in the form of pen names is now a powerful concept that goes to any extent to motivate the women folks to establish their freedom in the world of chaos. The women writers are the backbone of feminism and they 
SMART MOVES JOURNAL IJELLH e-ISSN: 2582-3574 p-ISSN: 2582-4406 VOL. 8, ISSUE 12, DECEMBER 2020

continue to hold together the varying aspects of their identity while inspiring others to do the same. 


\section{References}

Angelou, Maya. Phenomenal Woman: Four Poems Celebrating Women. New York: Random House, 1994.

Angelou, Maya. "Quote by Maya Angelou." Goodreads. Austen, Jane. Pride and Prejudice. New York, 1995.

Das, Kamala. “Kamala Das' Poems are Full of Raw Emotions \& These 10 Quotes will Prove It Once and for All." Vagabomb.

Das, Kamala. My Grandmother's House. English summary. Eliot, George. Adam Bede. New York: Harper, 1800.

Eliot, George. Middlemarch. London: Penguin Books,2003.

Eliot, George. The Mill on the Floss. Petersborough. Ont: Broadnew Press 2007.

Plath, Sylvia. Daddy. Poetry Foundation.

Plath, Sylvia. Lady Lazarus. Poetry Foundation.

Woolf, Virginia. A Room of One's Own. New York: Harcourt, Brace and Company,1929.

Woolf, Virginia. "Virginia Woolf Quotes." Goodreads. 